\title{
Moringa oleifera leaves methanolic extract inhibits angiotensin converting enzyme activity in vitro which ameliorates hypertension
}

\author{
Suraiya Aktar ${ }^{1}$, Plabon Kumar Das ${ }^{1}$, Saharia Yeasmin Asha ${ }^{1}$, Mst. Ayesha Siddika ${ }^{1}$, Farhadul Islam ${ }^{1}$, Jahan \\ Ara Khanam ${ }^{1}$, and Md. Abdur Rakib ${ }^{*}$ \\ ${ }^{1}$ Department of Biochemistry and Molecular Biology, University of Rajshahi, Rajshahi-6205, Bangladesh. \\ *Corresponding author: Dr. Md. Abdur Rakib, Department of Biochemistry and Molecular Biology, University of Rajshahi, Rajshahi-6205, \\ Bangladesh, Email: mar@ru.ac.bd
}

Academic Editor: Dr. Ataur Rahman, Korea Institute of Science \& Technology, South Korea. Received: 25 March 2019; Accepted: 15 May 2019; Published: 22 May 2019.

ABSTRACT: Angiotensin Converting Enzyme (ACE) regulates blood pressure. ACE converts angiotensin I to angiotensin II which binds with its receptors and through a cascade of reactions constrict blood vesels, consequently results in increased blood pressure, called hypertension. Inhibition of ACE activity is considered as an useful therapeutic target that reduce hypertension. Moringa oleifera leaves have traditionally been used in Ayurvedic medicine for their antihypertensive activity and antihypertensive effect of Moringa leaves was reported on spontaneously hypertensive rats. So, we hypothesize that Moringa oleifera leaves methanolic extract (MOLME) might inhibit ACE activity. Inhibition of ACE activity by MOLME was estimated in vitro. In this study, inhibition of ACE by MOLME was evaluated by spectrophotometric method. MOLME inhibited ACE activity in the substrate hippuryl-Lhistidyl-L-leucine $(\mathrm{HHL})$ with an IC50 value of $226.37 \mu \mathrm{g} / \mathrm{ml}$ with a reference compound, captropril (CP), a potent ACE inhibitor with an IC50 value of $0.0289 \mu \mathrm{M}$. The mode of ACE inhibition in HHL with or without MOLME revealed that the $\operatorname{Vmax}(0.0857$ and $0.0541 \mathrm{OD} / 30 \mathrm{~min}$, respectively) was changed and the $\mathrm{Km}$ values were 4.671 and 4.41. The results indicate that MOLME acts as a non-competitive inhibitor for ACE. CP was found a competitive inhibitor of ACE. MOLME might be a potential natural inhibitor of ACE which reduces hypertension.

KEYWORDS: ACE, HHL, moringa leaves, hypertension.

\section{INTRODUCTION}

Hypertension is one of the most important risk factors for cardiovascular diseases, which are the leading cause of mortality worldwide. Globally cardiovascular disease accounts for approximately 17 million deaths per year, nearly one third of the total [1]. In Bangladesh, approximately $20 \%$ of adult and $40-65 \%$ of elderly people suffer from hypertension [2].

The renin- angiotensin system (RAS) is a major clinical target for the treatment of hypertension [3]. RASmediated hypertension is initiated when renin stimulates the conversion of angiotensinogen to angiotensin I. Then, angiotensin converting enzyme (ACE) stimulates the conversion of angiotensin I to angiotensin II, which is a potent vasoactive peptide that causes blood vessels to constrict, resulting in increased blood pressure [4].

Moringa oleifera Lam (Moringaceae) is a highly valued plant, distributed in many countries of the tropics and subtropics including Bangladesh. In Bangladesh, the leaves, fruits, flowers and pods of this tree are used as a highly nutritive vegetables. Different parts of this plant contain a profile of important minerals, and are a good source of protein, vitamins, beta-carotene, amino acids and various phenolics. The Moringa plant provides a rich and rare combination of zeatin, quercetin, betasitosterol, caffeoylquinic acid and kaempferol. In 
addition to its compelling water purifying powers and high nutritional value, Moringa oleifera is very important for its medicinal value. Various parts of this plant such as the leaves, roots, seed, bark, fruit, flowers and immature pods act as cardiac and circulatory stimulants, possess antitumor, antipyretic, antiepileptic, anti-inflammatory, antiulcer, antispasmodic, diuretic, antihypertensive, cholesterol lowering, antioxidant, antidiabetic, hepatoprotective, antibacterial and antifungal activities, and are being employed for the treatment of different ailments in the indigenous system of medicine, particularly in South Asia [5]. Moringa oleifera leaves have traditionally been used in Ayurvedic medicine for their antihypertensive activity [6]. Moreover, Antihypertensive effect of Moringa leaves also evaluated on spontaneously hypertensive rats [7]. But the ACE inhibitory activity of Moringa leaves has not yet been studied.

Many drugs are available for the management of hypertension, even though most of them are rarely affordable. Currently, a tendency towards the use of natural products or alternative medicine, probably due to the fact that it is perceived to be a cheaper means of treatment. The objective of the study was to evaluate the ACE inhibitory activity of MOLME and its type of inhibition in vitro. Inhibition of ACE activity of Moringa oleiofera leaves extracts might be a cost effective and safer antihypertensive agent.

\section{MATERIALS AND METHODS}

\section{Chemicals}

Angiotensin converting enzyme (ACE), Hippuryl-Lhistidyl-L-leucine (HHL), O-Phthaldialdehyde (OPA), and Captoprill (CP) were purchased from Sigma, MO, USA. Sodium borate decahydrate (Borax), 2-mercapto ethanol were purchased from Carl Roth, Germany and all other reagents were analytical grade.

\section{Moringa oleifera leaves methanolic extract (MOMLE) preparation}

Moringa oleifera leaves were collected and dried in open air in room temperature in the laboratory. The dried leaves were grinded to powder and kept in a refrigerator. $100 \mathrm{~g}$ of powder was extracted with $300 \mathrm{~mL}$ of methanol by mixing, using a magnetic stirrer at room temperature for $2 \mathrm{~h}$. The extract was filtered through Whatman No.1 filter paper to obtain particle free extract. The residue was re-extracted twice and filtered. The extracts were pooled and concentrated using a rotary vacuum evaporator (Hahnshin Scientific, Korea). The extracts were kept in a refrigerator until analysis.

\section{ACE inhibition assay in vitro}

Inhibition of ACE activity by different concentrations of MOLME and CP were measured by spectrophotometric method as described previously [8]. Briefly, 20mM sodium borate buffer containing $0.3 \mathrm{M} \mathrm{NaCl}(\mathrm{pH} 8.3)$ was used for the preparation of MOLME, CP, ACE, and substrate HHL solutions. The ACE-catalyzed reaction was performed for $30 \mathrm{~min}$ at $37^{\circ} \mathrm{C}$ in test tubes of the following compositions: $100 \mu \mathrm{L}$ of MOLME or CP, 100 $\mu \mathrm{L}$ of ACE solution $(40 \mathrm{mU} / \mathrm{mL})$, and $100 \mu \mathrm{L}$ of $\mathrm{HHL}$ (15 mM) solutions (A1); $100 \mu \mathrm{L}$ of MOLME or CP solution and $200 \mu \mathrm{L}$ of borate buffer (A2); $100 \mu \mathrm{L}$ of borate buffer, $100 \mu \mathrm{L}$ of ACE solution, and $100 \mu \mathrm{L}$ of HHL solution (A3); and $300 \mu \mathrm{L}$ of borate buffer (A4). The enzymatic reaction was stopped by adding $3 \mathrm{~mL}$ of alkaline solution of OPA solution $(\mathrm{pH}$ 12.0). The absorbance of each reaction was measured at 390nm using a HITACHI U-1800 Spectrophotometer (Japan), after incubation for $20 \mathrm{~min}$ at $25^{\circ} \mathrm{C}$. Inhibition of ACE by MOLME or $\mathrm{CP}$ was calculated using the following equation: inhibition $(\%)=[1-(\mathrm{A} 1-\mathrm{A} 2) /(\mathrm{A} 3-\mathrm{A} 4)] \times 100$. The $\mathrm{IC}_{50}$ value of $\mathrm{ACE}$ activity was calculated by the equation $\mathrm{IC}_{50}=(50-\mathrm{b}) / \mathrm{m}$ derived from a linear regression graph of ACE activity, where $b$ is the intercept and $\mathrm{m}$ is the slope of the equation.

\section{Determination of kinetic parameters of ACE inhibition}

Kinetic parameters of $\mathrm{Vmax}$ and $\mathrm{Km}$ values were determined according to the Michaelis-Menten kinetic model [9]. The reaction rate for the formation of Lhistidyl-L-leucine from HHL by ACE $(40 \mathrm{mU} / \mathrm{mL})$ was determined by the above-mentioned method with MOLME $(226.37 \mu \mathrm{g} / \mathrm{ml})$ or CP $(0.0289 \mu \mathrm{M})$ and without MOLME or CP to get the saturation curves and then plotted against HHL concentrations (1.85, 3.75, 7.50,15 $\mathrm{mM})$. The Line weaver-Burk plot was derived using the saturation curves to determine the type of inhibition. Kinetic parameters ( $\mathrm{Km}$ and $\mathrm{Vmax}$ ) were calculated using MS Excel.

\section{Statistical analysis}

The results are expressed as the percentage of ACE inhibition. All data were expressed as the mean \pm SD. The statistical analysis of data was performed using SPSS for Windows version 11 (SPSS, Inc., Chicago, IL, USA). 


\section{RESULTS}

\section{ACE inhibition}

ACE plays a key role in blood pressure regulation [4, 10-12]. ACE converts angiotensin I to angiotensin II which causes the contraction of blood vessels and thereby leads to hypertension. Inhibition of ACE activity by MOLME was measured by ACE inhibition assay with reference compound, $\mathrm{CP}$, which is a potent inhibitor of ACE [13]. Fig. 1 and Fig. 2 show ACE inhibition activities of MOLME and $\mathrm{CP}$ at different concentrations, respectively. The $\mathrm{IC}_{50}$ value for $\mathrm{ACE}$ inhibition by MOLME was found at $226.37 \mu \mathrm{g} / \mathrm{ml}$. IC 50 of $\mathrm{CP}$ was $0.0289 \mu \mathrm{M}$. This result indicated that MOLME has ACE inhibitory activity which might be a candidate for lowering hypertension.

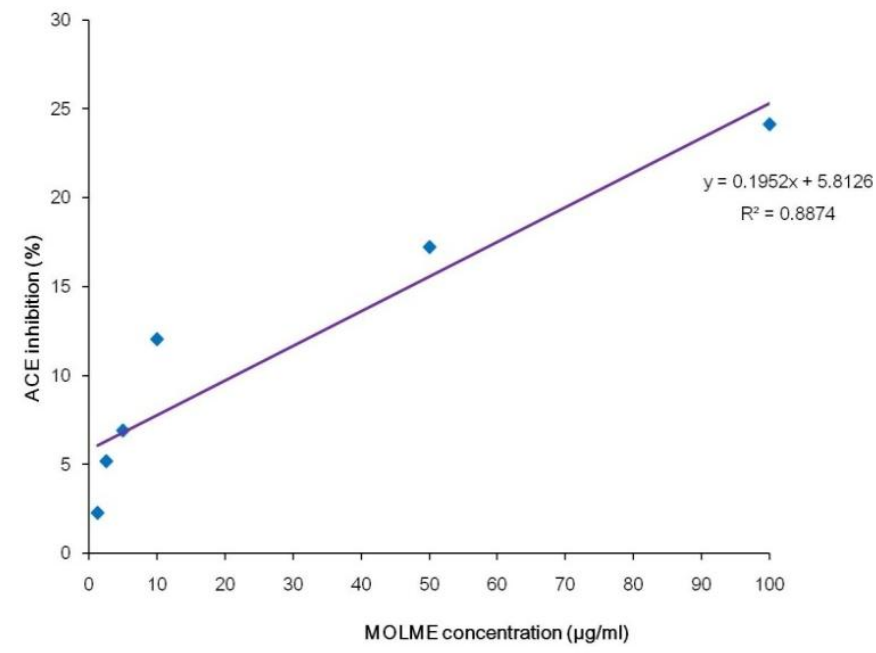

Figure 1. Inhibition of ACE activity by MOLME. IC50 value of MOLME was calculated to be $226.37 \pm 0.021 \mu \mathrm{g} / \mathrm{ml}$. The results are expressed as the percentage of ACE inhibition. The plot represents the mean \pm SD from three experiments.

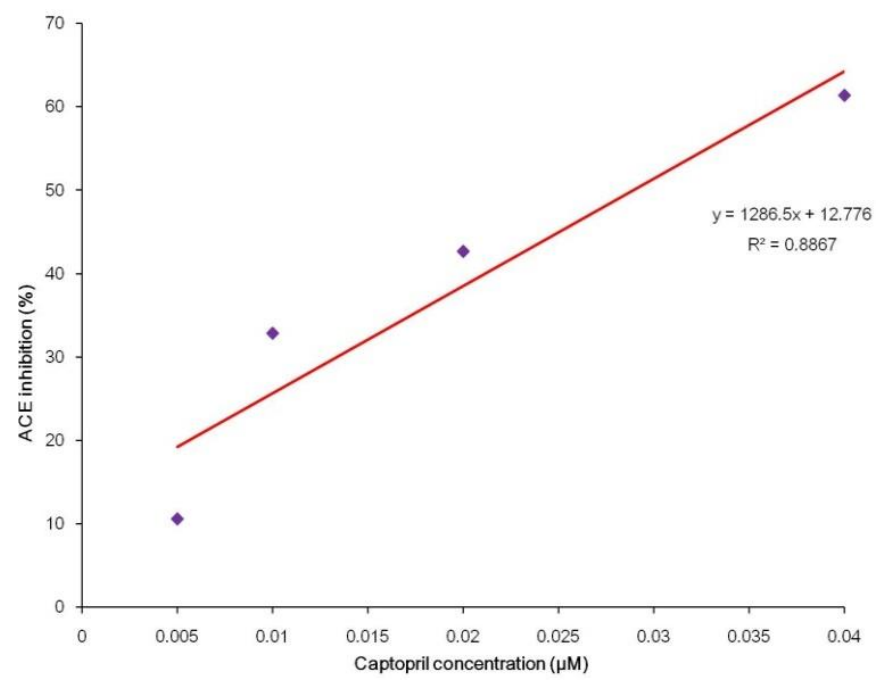

Figure 2. Inhibition of ACE activity by CP. IC50 value was calculated to be $0.0289 \pm 0.011 \mu \mathrm{M}$. The results are expressed as the percentage of ACE inhibition. The plot represents the mean $\pm \mathrm{SD}$ from three experiments.

\section{Type of ACE inhibition mechanism}

The mode of action of MOLME in ACE inhibition at various HHL substrate concentrations (Fig. 3 and Table 1) was also determined. The $\mathrm{Km}$ values of the ACE activity were found to be 4.507 and 4.42 for no inhibitor and MOLME respectively and Vmax values were 0.0842 and 0.0463 . These results indicate that ACE activity inhibition was by MOLME as a non-competitive inhibitor.

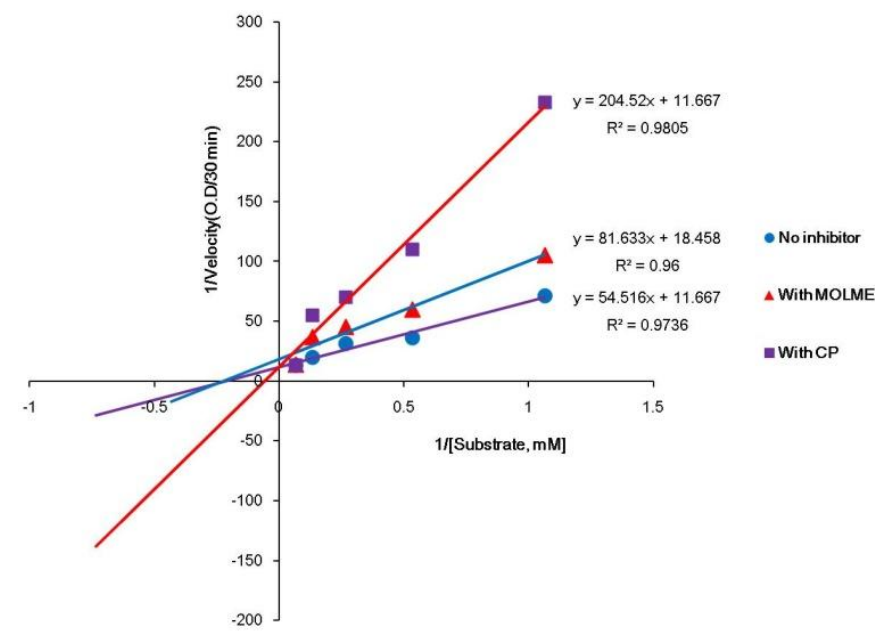

Figure 3. Lineweaver-Burk plots for the inhibition of ACE by MOLME $(226.37 \mu \mathrm{g} / \mathrm{ml})$ and CP $(0.0289 \mu \mathrm{M})$. The plot represents the mean $\pm \mathrm{SD}$ from three experiments.

Table 1. ACE inhibition and Kinetic Parameters by MOLME

\begin{tabular}{|c|c|c|c|}
\hline 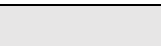 & 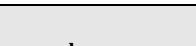 & Kinetic param & eters ${ }^{a}$ \\
\hline Compound & $\mathrm{IC}_{50}^{\mathrm{b}}$ & $\begin{array}{l}V \max \\
(\mathrm{OD} / 30 \mathrm{~min})\end{array}$ & $K m(\mathbf{m M})$ \\
\hline no inhibitor & & 0.0857 & 4.671 \\
\hline MOLME & $\begin{array}{l}226.37 \pm 0.021 \\
\mu \mathrm{g} / \mathrm{ml}\end{array}$ & 0.0541 & 4.41 \\
\hline $\mathrm{CP}$ & $\begin{array}{l}0.0289 \pm 0.011 \\
\mu \mathrm{M}\end{array}$ & 0.0857 & 17.52 \\
\hline
\end{tabular}

$\overline{{ }^{a}}$ Kinetic parameter was calculated from Fig. $\mathbf{3}^{\mathbf{b}}$. IC 50 was calculated from Fig. 1 and 2.

\section{DISCUSSION}

The objective of this study was to evaluate whether MOLME have ACE inhibitory activity. The present study revealed that MOLME has ACE inhibitory activity in vitro with an $\mathrm{IC}_{50}$ of $226.37 \mu \mathrm{g} / \mathrm{ml}$ and $\mathrm{CP}$ has shown inhibition $\mathrm{IC}_{50}$ of $0.0289 \mu \mathrm{M}$, which is a strong competitive inhibitor of ACE [8] as shown in fig. 1 and 2. Like CP, several ACE inhibitory agents, such as, eritadenine [8], and snake venom [14] were shown to 
have competitive inhibitory activity. In the present study, MOLME was found to have non-competitive ACE inhibitory activity as shown in Fig. 2 and Table 1 and this is the first report of MOLME as an ACE inhibitor which was compared with $\mathrm{CP}$, a potent competitive ACE inhibitor.

Analysis of kinetic properties gives the mechanism of MOLME to inhibit ACE activity, along with the quantity required either for the reaction to continue or for ACE activity to be inhibited [8, 14-17]. Line Weaver-Burk plot for ACE reactions in various concentration of HHL with MOLME $(226.37 \mu \mathrm{g} / \mathrm{ml})$ or without MOLME revealed that Vmax 0.0541 and 0.0857 respectively. Vmax increased MOLME and $\mathrm{Km}$ increased from 4.41 to $4.671 \mathrm{mM}$ HHL, indicating noncompetitive inhibitor (Fig. 3 and Table 1). There was no previous data MOLME in the literature to compare. Same Vmax and increased (variation) in $\mathrm{Km} 4.671$ and 17.52 were found for no inhibitor and $\mathrm{CP}$ which indicate competitive inhibitor. In previous different studies, CP has shown competitive inhibitor of ACE similar to our study (Fig. 3 and Table 1).

Therefore, the results indicate that MOLME is a noncompetitive inhibitor which may bind different site of the enzyme other than the active site. MOLME may bind either with the free enzyme or enzyme-HHL complex.

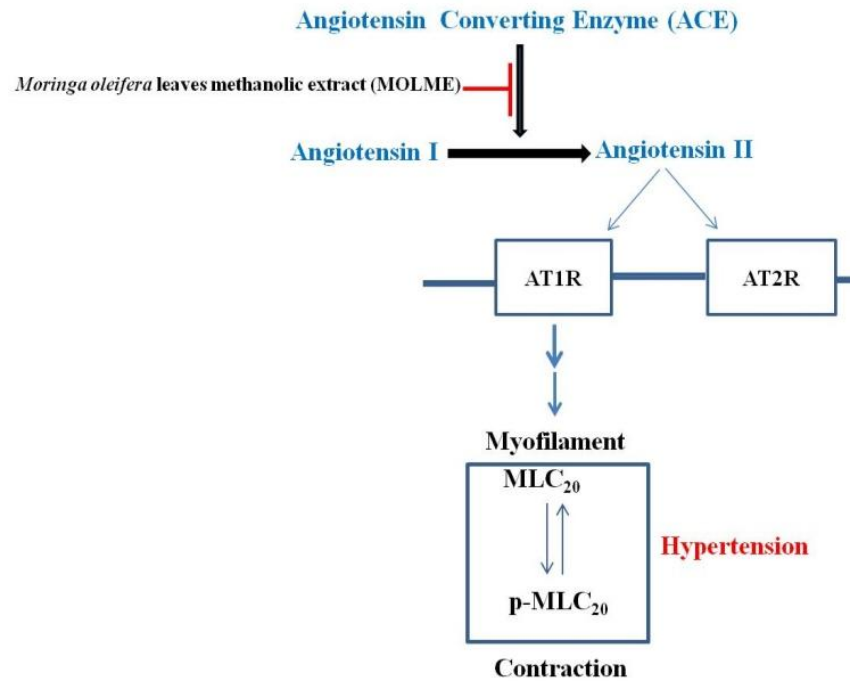

Figure 4. Diagram showing the possible effect of MOLME on ACE activity in hypertension.

\section{CONCLUSION}

In conclusion, this study, first reported that MOLME have ACE inhibitory activity with an $\mathrm{IC}_{50}$ of $226.37 \mu \mathrm{g} / \mathrm{ml}$. This result suggests that editable Moringa oleifera leaves could be useful for the treatment of hypertension (Fig. 4). Further research is needed to clarify the antihypertensive action of MOLME in vivo.

\section{ACKNOWLEDGEMENT}

This study was supported by a grant from Ministry of Science and Technology, Peoples Republic of Bangladesh under "Special Allocation for Science and Technology" program 2016-2017 (GO NO:39.00.0000.09.02.6916-17/14 MEDI'S, Gr. serial no. 249).

\section{AUTHOR CONTRIBUTIONS}

Suraiya Aktar and Plabon Kumar Das were involved in conception and design and perform the experiments. Saharia Yeasmin Asha and Mst. Ayesha Siddika analyzed data. Md. Abdur Rakib contributed to drafting the article. Farhadul Islam and Jahan Ara Khanam contributed to revising it critically for important intellectual content. Md. Abdur Rakib made the final approval of the version to be published.

\section{CONFLICTS OF INTEREST}

The authors declare that there is no conflict of interests.

\section{REFERENCES}

[1] Papadogiannis DE, Protogerou AD. Blood pressure variability: A confounder and a cardiovascular risk factor. Hypertension Res. 2011; 34(2): 162-163.

[2] Monwarul Islam AKM, Abdullah AS, Majumder. Hypertension in Bangladesh: a review. Indian Heart J. 2012; 64(03):319-323.

[3] Ma TK, Kam KK, Yan BP, Lam YY. Renin-angiotensin aldosterone system blockade for cardiovascular diseases: current status. Br J Pharmacol. 2010; 160: 1273-1292.

[4] Hammoud RA, Vaccari CS, Nagamia SH, Khan BV. Regulation of the renin- angiotensin system in coronary atherosclerosis: a review of the literature. Vasc Health Risk Manage 2007; 3: 937-945.

[5] Anwar F, Latif S, Ashraf M, Gilani AH. Moringa oleifera: a food plant with multiple medicinal uses. Phytother Res. 2007; 21(1): 17-25.

[6] Dangi SY, Jolly CI, Narayan S. Antihypertensive Activity of the Total Alkaloids from the Leaves of Moringa oleifera. Pharm. Biol. 2002; 40(2): 144-148.

[7] Kajihara R, Nakatsu S, Shiono T, Shibatak K et al. Antihypertensive effect of water extracts from leaves 
of Moringa oleifera Lam. on spontaneously hypertensive rats. J Jpn Soc food Sci 2008; 55(4):183-185.

[8] Sadia Afrin, Md. Abdur Rakib, Boh Hyun Kim, Jeong Ok Kim and Yeong Lae Ha. Eritadenine from Edible Muhrooms Inhibits Activity of Angiotensin Converting Enzyme in Vitro. J Agric Food Chem. 2016; 64: 2263-2268.

[9] Ojeda D, Jimenez-Ferrer E, Zamilpa A, HerreraArellano A, Tortoriello J, Alvarez L. Inhibition of angiotensin convertin enzyme (ACE) activity by the anthocyanins delphinidin- and cyanidin-3Osambubiosides from Hibiscus sabdariffa. J. Ethnopharmacol 2010; 127: 7-10.

[10] Akif M, Georgiadis D, Mahajan A, Dive V, Sturrock ED, et al. High resolution crystal structures of Drosophila melanogaster angiotensin-converting enzyme in complex with novel inhibitors and antihypertensive drugs. J Mol Biol. 2010; 400: 502-517.

[11] Fleming I. Signaling by the angiotensin-converting enzyme. Cardiovasc Res. 2006; 98: 887-896.

[12] Koike H, Ito K, Miyamoto M, Nishino H. Effects of long-term blockade of angiotensin converting enzyme with captopril (SQ14, 225) on hemodynamics and circulating blood volume in SHR. Hypertension 1980; 2: 299-303.

[13] Jurca T, Vicas L. 2010. Complexes of the ACE-inhibitor captopril. Farmacia 2010; 58: 198-202.

[14] Bryan, J. From snake venom toACE inhibitor-the discovery and rise of captopril. Pharm. J. 2009; 282: 455 .

[15] Yahaya NFM, Rahman MA, Abdullah N. Therapeutic potential of mushrooms in preventing and ameliorating hypertension. Trends Food Sci. Technol. 2014; 39:104-115.

[16] Girgih AT, Udenigwe CC, Li H, Adebiyi AP, Aluko RE. Kinetics of enzyme inhibition and antihypertensive effects of hemp seed (Cannabis sativaL.) protein hydrolysates. J Am Oil Chem Soc. 2011; 88: 1767-1774.

[17] Onuh JO, Girgih AT, Malomo SA, Aluko RE, Aliani M. Kinetics of in vitro renin and angiotensin converting enzyme inhibition by chicken skin protein hydrolysates and their blood pressure lowering effects in spontaneously hypertensive rats. J Funct. Foods 2015; 14: 133-143. under the terms of the Creative Commons Attribution Non-Commercial License, which permits unrestricted non-commercial use, distribution, and reproduction in any medium, provided the original work is properly cited. 